\title{
Gesturing Toward Utopia: Toward a Theory of Exemplarity
}

\author{
DOROTHY NOYES \\ Ohio State University
}

\begin{abstract}
Summarizing a 2015 SIEF panel, the paper seeks to synthesize folkloristic and ethnological resources for developing a theory of exemplarity as a special case of tradition, not marginal but central to Western discourses of power, progress, and the self. The exemplar is a particular individual whose act or conduct is claimed, through gesture, in a subsequent performance. Following the papers from the panel, I review the gestural core of exemplarity, the problem of uptake, ideologies of exemplarity, and exemplarity in the social field, all through the constitutive tension in the concept between the model and the representative.
\end{abstract}

Keywords: exemplarity, gesture, performance, political symbolism, individual, attention economy

What does a social norm look like? When public figures talk about "values" they are usually pleased to stay abstract rather than committing themselves to particular patterns of conduct that might limit their own freedom of action. In argument and in pedagogy, however, we often need to clarify. This is done by pointing to an example: the conduct or action of a real human being that can be made to illustrate a principle, either affirmatively or negatively. Western languages share a rich emic vocabulary of exemplarity. We know what it is to set an example, to lead by example, to make an example of someone, to be an exemplary student or husband and father. In related discourses, we worry about whether children have positive role models or are falling under bad influences; we talk of the heroes that have inspired us.

Folklorists and ethnologists have long studied aspects of exemplarity. Most obviously, enumerations of the minor genres of folk narrative include the exemplum: a short anecdote, especially associated with Christian preaching, used to illustrate a point of conduct (e.g. Brémond, LeGoff, and Schmitt 1996). In studies of popular imaginaries we have anatomized various exemplary figures: the hero, the saint, the ancestor, the martyr, the outlaw, the villain, and more recently the celebrity (e.g. Raglan 1936; Schmitt 1983; Roberts 1990; Povedák 2014). Approaches to verbal performance consider 
the uses of allusion and indexicality as they invoke a prior authority for present discourse (e.g. Briggs and Bauman 1992; Hill and Irvine, eds. 1993). More embodied approaches speak of register, mimesis and self-fashioning, appropriation, and even reenactment in relation to idealized personae (e.g. Cantwell 1993; Agha 2007; Mendoza-Denton 2008). Studies of communities and social movements consider founding narratives or "root paradigms" in which individual models often play a strong role (Turner 1975).

In this essay I assemble some initial thoughts about how we might build a more cumulative disciplinary conversation on exemplarity. Viewed holistically, exemplarity is a complex of practices held together by reflexive interplay between the conduct of individuals, the creation and transmission of narratives and images, the formation and reformation of social agendas, and emic discourses of exemplarity itself. I draw from the panel "Gesturing Toward Utopia: The Politics of Exemplarity," organized for the Zagreb SIEF conference in 2015, to consider the constitutive tension in the concept, the gestural core of exemplarity, the problem of uptake, ideologies of exemplarity, and exemplarity in the social field.

A conference panel with an open call for papers, according to the SIEF procedure, opens the way to serendipity. Like exemplarity itself, the SIEF process works between planning and contingency. Our panel had fewer submissions than I had hoped for, a few submissions I could not see how to work in, and a late funding-related cancellation. But an unanticipated paper turned up, raising issues I had not considered. With careful listening and commentary from a lively audience, ${ }^{1}$ the four papers proved to be complementary and mutually illuminating in ways we had not anticipated.

Elizabeth Rainey of the Higher Colleges of Technology, United Arab Emirates, presented a paper on Shamsa al Falahi, a Bedouin woman poet in her eighties, who has domesticated the al Nabati genre of oral satire to her own purposes (Rainey 2015). Shamsa builds on a genre devoted to upholding the al adab, the Bedouin ideal of conduct, to affirm an exemplary pastoral legacy in an Emirati household that today is affluent and globalized. By extension, these performances reinforce the poet's own authority and autonomy within her family.

István Povedák of the Hungarian Academy of Sciences and University of Szeged described the paradoxes of Roma celebrity in Hungary (Povedák 2015). Arguing that celebrities have replaced traditional heroes as societal "points of orientation," he demonstrated the limits of agency, representation, and mobility in the public image of Roma athletes and musicians. The need for "role models" is enjoined on the Roma, but celebrity is the only mode of

\footnotetext{
${ }^{1}$ Special thanks to Dani Schrire, Fabio Mugnaini, Deborah Kapchan, and others in that audience, as well as to Stefan Groth for additional suggestions. Thanks above all to the panelists whose research and ideas shaped this synthesis.
} 
visibility society accords to them, creating a mismatch in which Roma public figures are perpetually seen to fall short. By contrast, their actions with exemplary potential do not receive media coverage.

Yücel Demirer of Kocaeli University examined an incident at the 2009 meeting of the World Economic Forum in Davos: Turkish president Recep Tayyip Erdoğan was cut off by a moderator at the end of a panel and walked out, protesting that Israeli president Shimon Peres had been given more time to speak (Demirer 2015). Commentators in Turkey and around the Middle East turned Erdoğan's gestural response into an icon of resistance to Western bias and hypocrisy. The power of this exemplum temporarily overrode, to some extent, deep divides in Turkey over Erdoğan's leadership.

Katherine Borland of the Ohio State University examined the transformation of victims into martyrs through protest performance (Borland 2015). Comparing mimetic commemorations of Latin American victims of military repression and African American victims of police violence, she showed how gestures of innocent fear and suffering are repurposed as expressions of righteous anger and political challenge. She considered the circumstances under which one who is made an example of can provide a template for transformative social action and described the "techniques of identification" that enable reactivation but also appropriation.

\section{VORBILD AND BEISPIEL: MODEL OR REPRESENTATIVE?}

Diverse as these papers were, they pointed immediately to tensions within the concept of exemplarity: between hero and stereotype, between ethos and movement, between offer and uptake. There is, however, a deeper and constitutive tension in the Latinate lexeme example - one that is spelled out in the German distinction between Vorbild and Beispiel. A Vorbild is, literally, a picture in front of you: a model to be emulated. A Beispiel is an example of something, a concrete illustration of an abstract proposition.

In contrast, example and exemplary are thoroughly ambiguous. Is the example exceptional or representative? Is it normative or descriptive? Ideally it is both. Like the work of art described by Lévi-Strauss, it is a blend of pattern and event (1962: 36-37). To further complicate matters, the Beispiel cited to illustrate a point is not necessarily representative at all: it may simply be convenient to hand. And here we must consider the economy of attention (Noyes 2016, chapter 5), for what is convenient to hand is often manufactured and distributed for that purpose. Povedák speaks of the celebrity as simply a "point of orientation" in an information-crowded society. Images that are easy to find and available to the majority carry more weight than images that must be sought out, pointed out, and explained. Emphatic, mobile 
images command more attention than real, situated individuals. This is why the question of public images and emblems of marginalized populations has become so fraught a topic: ideologically inflected or simply commercially viable representations induce misrecognition of real persons.

I will not address the Beispiel side of the question in detail: the relevant issues of representation and allegorization, identification and empathy have been well considered already (e.g. Shuman 2010). I deal with the Vorbild component: with the exemplar as one that stands forward to be imitated, or is claimed after the fact for rhetorical or pedagogical purposes. Still, the conflation of the two concepts in English and the Romance languages is worth considering. To serve its purpose, an example must somehow fall within the social reach of its follower; some link must enable identification sufficient for mimesis to be thinkable.

\section{GESTURE}

When we think of exemplars in social life, a snapshot image often comes to mind, capturing a decisive gesture: American civil rights activist Rosa Parks on December 21 ${ }^{\text {st }}, 1956$, refusing to get up from her seat at the front of the Montgomery bus; German Chancellor Willy Brandt on December $7^{\text {th }}, 1970$, suddenly kneeling in front of the Warsaw Ghetto memorial during a groundbreaking state visit to Poland; the Chinese student standing in front of the tanks on Chang'an Avenue at Tiananmen Square in May 1989. If an example is to be followed, it must provide something recognizable to imitate.

Insight into the gestural core of exemplarity can be found in an old piece of folklore scholarship. In his 1930 treatise on the "simple forms" of folklore, André Jolles posited that imitation was one of the primary cognitive operations impelling the formation of cultural genres (Jolles 2011: 36). Specifically, the impulse toward imitation shapes the basic form that Jolles calls the Legende. This is not what is meant today by the word legend in English-language scholarship, but comes from the Latin for a hagiographic narrative, a saint's legend recounting the virtues, martyrdom, and miracles of a Christian exemplar. Jolles extends the term to other kinds of hero narratives, even to the accounts of athletic exploits found in contemporary sports journalism. For Jolles the defining feature of such a narrative is, in fact, the gesture.

Here too Jolles accords a meaning of his own to the term. In the Legende, the gesture is a concrete detail, often of a violent character, that confers specificity on the narrative (2011: 48-50). In contemporary terms we would speak of the salience by which it lends itself to memory. The attribute of a saint in Christian iconography is an index that has become an emblem. Jolles emphasizes the pictorial character of the gesture, realizing an abstract virtue 
(fortitude, strength) as something visualizable, graspable, and particular: the wheel on which St. Catherine is tortured, or Jack Dempsey's knockout punch. ${ }^{2}$

Capturing the particularity of the incident in which an example is set, the gesture allows the incident to be restored to the present through citation and reenactment. Shamsa el-Falahi's poem reworks Bedouin pastoral as she justifies maintaining and caring in person for her family's old goat herd, even though the eighty-year-old poet is chauffeured to their grazing grounds in a luxurious black SUV: "I cruise to the field in my dark, velvet ride." The Roma celebrities described by Povedák identify and authenticate themselves by emblematic Roma behavior: joking around, performing a song. Erdoğan's gesture is revived in citation, with t-shirts proclaiming "One minute!" and illustrating the jab of the President's finger toward the session moderator: Demirer establishes that this "historic slap" and not the gesture of disengagement represented by walking off stage became the emblem of the incident. Activists in Borland's case study reenact gestures of aggression or desperation with chants of "Hands up! Don't move!" or "I can't breathe." In each case, an immediate situation is summed up, and simultaneously a gesture is made toward a broader context of interpretation: a compromised state of things, an ideal order from the past, a possible future.

The gesture is mutable and malleable: it can circulate from body to image to language, or join all these modes in one. It is rooted, however, in the "natural symbol" of the body and its deployment in space and time (Douglas 1970). Gestures in the more usual sense construct social and conceptual relationships: pointing, aligning, distancing, interpreting, externalizing mental states, reaching toward imagined possibilities (Young 2011). Along with the mobile gestures of arms and hands we must also consider bodily stances and their associated orientations: standing up, kneeling down, walking out, sitting in, not being moved. In the context of mass society's manipulations of individuals, stance takes on special importance as a refusal to be swayed. The famous photograph of Rosa Parks sitting alone in the front of the now halted bus, a US Marshal behind her, shows her not only still but calm, gazing out the window as if lost in thought. She is not a specimen of a subordinated class but a detached, reflective individual, dignified because she is self-contained.

The embodied core of the gesture has an important consequence: it lodges exemplarity in the conduct of individuals, those spiritual entities encased within single biological bodies. ${ }^{3}$ Indeed it reinforces the status of the

\footnotetext{
${ }^{2}$ A similar conception exists in operatic theory, with what Ferruccio Busoni called the Schlagwort: the musical gesture that provides an abridgment or epitome of the dramatic situation; Bertolt Brecht's gestus offers a related theatrical formulation with more explicit political implications.

${ }^{3}$ See Cashman, Mould, and Shukla eds. (2011) for an overview of individuals as practitioners of tradition, and Cashman 2008 for individuals as the subjects of tradition in local character anecdotes: this latter approach brings us toward exemplarity as I am describing it here.
} 
individual through its holistic mobilization around the body as a bounded entity. Fragmented or "dividual" as we may be through our varied engagements and inputs, social roles and guises (Fernandez 1986: 188-189), the gesture is holistic and mobilizes the whole ensemble of what we are through the single continuous organic entity that holds that ensemble together. The gesture might even be taken as evidence for the reality of the individual, a line of argument developed in French existentialism.

Paradoxically, however, we must return to Jolles' imitatio. For gestures have a lineage: they point not just out to a social context but back toward a prior exemplar. In some cases this is a reenactment, appropriation, or reproduction that tries to minimize intertextual gaps (Briggs and Bauman 1992) and magnify an effect, as in the "I can't breathe!" of today's \#BlackLivesMatter protesters or, indeed, the successive sit-ins at lunch counters across the American South during the Civil Rights movement. At other times the gesture seeks to appropriate the power of a precursor through performance, an invocation that may be judged as earned or as spurious. In Bakhtinian terms, gestures, like verbal utterances, are double- or multi-voiced, carrying the resonance of earlier voicings (1982). The remembered voices are sometimes in discord, sometimes in harmony with the present.

A gesture understood as not imitative of an example but exemplary in its own right does not reproduce but revises a prior gesture. After the photograph of Willy Brandt at the memorial to Warsaw's murdered Jews went round the world, an editorial from the right-wing Bund der Vertriebenen, the federation of ethnic Germans expelled from Eastern Europe after 1945, demanded "Did the Chancellor of the Federal Republic of Germany have to go to Canossa?" (Müller 2012: 469). Canossa is the Italian castle within which, in 1077, the Pope waited for three days as the excommunicated German emperor Henry IV knelt outside in the snow to declare his submission. That gesture was invoked and reversed in 1872 by the chancellor of German unification, Otto von Bismarck, during the struggle between secular Protestant Prussian government and the Catholic church: Bismarck famously declared that Germany would never again go to Canossa, that is, would never again submit itself to external authority. Brandt undid this reversal in turn, announcing precisely such a submission to world opinion but also, unlike the emperor, doing so freely and voluntarily.

A fortieth-anniversary commemoration invoked other German exemplars: "Der Kanzler hat gekniet": the Chancellor has knelt (Wolffsohn and Brechenmacher 2010). This phrasing echoed the gestural heart of a core German political fiction, Schiller's Don Carlos: "Der König hat geweint." In Schiller's 1798 play, the weeping of the Spanish monarch Philip II shocks his courtiers, exposing the fragile membrane between human feeling and reasons of state. In fear of his own weakness, the king will submit to the Grand Inquisitor 
and root out the last impulses of his own humanity in order to maintain the vulnerable periphery of his empire (Noyes 2013). On the contrary, Brandt's move was seen as marking a watershed in the other direction: away from the aggrandizement of state power and the inquisitorial repression of the Other in favor of human feeling that cuts across borders.

Brandt's gesture was powerful in being simultaneously resonant and transgressive, falling out of protocol to pay a debt that Germany had not yet acknowledged. In Weberian terms, we could say that it linked Brandt's rational-legal role as German representative to both the traditional and the charismatic modes of political authority. With this thick range of references, Brandt's gesture brought out the large contour of a political tradition as it unfolds in time: Germany's past was recalled, Germany's future was modelled.

Not surprisingly given their complexity, exemplary gestures are in many cases not spontaneous but in fact designed to be exemplary. Rosa Parks' action was the fruit of planning and reflection by one trained in protest tactics and in consultation with a broader movement, taken when the moment seemed ripe (Theoharis 2013, chapter 4). Brandt's Kniefall was likewise at least partially thought out beforehand, with at least some discussion among his aides (Fischer and Lorenz 2007: 189-91). Planned gestures often backfire or go unnoticed, and even when effective they are not in themselves decisive. The Civil Rights movement involved complex coordinated action, much of it gestural, on many fronts; without Parks' action in the bus protest the changes would have happened anyway. In the short term, Brandt's gesture largely failed to impress its most immediate intended audience, the state of Israel and the German Jewish establishment, and it divided West German public opinion. If anything, in forcing a debate over its appropriateness, the Kniefall can be said to have been efficacious in pushing Germany publically towards Vergangenheitsbewältigung, the coming to terms with the Nazi past. In any case, these gestures played a signalling or indexical role. They were not just imitable but, as Jolles posits, graspable: something to point to as evidence that something was happening.

Gesture constrains and enables the possibilities of exemplary performance. Like all cultural forms, gesture carries the history of its use, but its very form as an isolable, identifiable entity makes it detachable, easily lifted out of one context and carried to another (Bauman and Briggs 1990). Its moral force tends to diminish with social distance and a loss of shared context between performer and audience (Noyes 2013).

Like culture in general, the gesture is by nature a public, nonrival good that one actor can use without excluding another from access to it. This availability makes the gesture vulnerable to recontextualization in settings that may be divisive, to appropriation for nonconsensual projects; it also opens 
it to overuse and loss of impact, even to commodification. ${ }^{4}$ More often than not, the noun gesture is modified with the adjective empty. The gesture does not always point us back to a full Legende; sometimes it is only a gesture.

\section{IMPACT AND UPTAKE}

The information economy extends the potential reach of gesture while diminishing its force (Noyes 2016, chapter 5). Attention is a scarce resource, and if you make a gesture when no one is looking, you cannot set an example. ${ }^{5}$ Slow exemplarity, founded in conduct over the long term as continually observed by others, belongs to the stable dense multiplex networks that are, today, increasingly rare social formations (Noyes 2016, chapter 2). The watershed gestures of Brandt and Parks took shape in a limited modern public sphere of newspapers and national television networks. In contrast, the fast exemplarity of gesture suffers from the intensity of the twenty-four hour news cycle in a globalized and open media environment. The viral action has no guarantee of staying power for the long term.

What kind of action does make an impact? No one denies the force of rhetoric, but it is ephemeral, open to later reversal and revision, its sticking power vulnerable to outcomes and later performances. Durable cultural creation demands time and resources; it is incremental and does not lend itself to easy imaging. On the contrary, to smash things is telegenic: the very metaphor of impact suggests an inherent violence to exemplarity. A moment of impact is easily captured and circulated, while its aftermath may be of long duration and broad social reach. Brandt, Parks, and the Chinese student, with their stances against a background of aggression, are salient as exceptions to this rule, but the success of their nonviolent approach depended on a broadcast mediasphere in which they were guaranteed attention. In the digital realm there is no place for stillness, and the kinetic requirement fosters a pattern of escalation in both verbal and material violence: towers must fall to achieve real notice. Hence the most memorable - and most emulated - gestures of our unhappy days are mass shootings, acts of terror, and assertions of contempt. What affirmative gesture of today has had the exemplary impact of the Charlie Hebdo shootings or of Donald Trump's "You're fired"?

Exemplarity is performance. Its efficacy depends as much on audience uptake as on the performer's intentions and design, with the manipulation of

${ }^{4}$ There is a rise in attempts to trademark gestures of acknowledged public significance, such as the "Let's roll" uttered on Flight 93 on 9-11 (Suellentrop 2002); Demirer records multiple applications to trademark "One minute." Such applications have so far been unsuccessful.

${ }^{5}$ Of course an action that is archived remains available for potential recovery as an example. 
shared inherited forms as the bridge between the two. Context may or may not be shared. It is possible for an example to be claimed a posteriori, a new actor seeing a precursor where no transmission in that direction had necessarily been intended. The victims of violence considered in Borland's paper had certainly not sought out martyrdom. Conversely, many would-be models find no followers. Dayan and Katz define the "felicity conditions" of large-scale media events in terms of a contract between sponsors, performers, broadcasters, and public (1994). They note that each partner can undermine the contract in a variety of ways, and that established arrangements can also be hijacked by outside actors to generate a successful performance of their own, as when the Black September terrorists took advantage of the 1972 Olympic Games in Munich to commit a high-profile assault on the Israeli team. In the same way, we can see exemplarity in terms of a contract, or at any rate a cooperation, among social actors, the makers of representations, onlooker-receivers, and possibly also institutional sponsors and promoters (Bauman 1986; Noyes 2001). A strongly designed action (whether planned or intuitive), an effective depiction in audience-appropriate media, citation and exhortation from influential authorities, all help an example to be set and made available. But uptake makes the exemplar, and it is in uptake that we find the emergent character of exemplarity, as of all performance (Bauman 1977).

\section{IDEOLOGIES OF EXEMPLARITY}

Uptake is affected, to varying extents, by ideology: the extent to which a conscious conception of exemplarity is held and propounded in a given social milieu, and the nature of that conception. In Western cultural history (the only tradition of which I am qualified to speak), exemplarity has long been socially recognized and encoded in norms. Certain categories of persons are to be looked to for examples, and are thus expected to conduct themselves in exemplary fashion; certain categories of persons are expected to follow examples set for them. These ideologies shift with shifting conceptions of authority and the individual, but older patterns and habits persist alongside new ones. Borrowing our categories from Raymond Williams (1977), we may thus think of residual, dominant, and emergent exemplarities.

Various older formulations of exemplarity persist. The early modern principle of "making an example" by punishing one criminal or rebel in spectacular fashion in order to discourage others (Foucault 1975) would today be disavowed by most formal authorities, yet it is widely practiced across the world in the disciplining of incarcerated, minority, and dissenting populations and also between states in the avowed anarchy of international relations. 
The converse mode of residual exemplarity is positive and used to legitimate privilege, especially the inherited privilege now said to be anachronistic. As the centralizing or absolutist states of early modern Europe sought to "domesticate" their unruly aristocracies by moving them from their provincial power bases to the court in the capital, a new justification for noble privileges had to be generated. No longer, as under the feudal order, "the ones who fight" for the defense of the realm, the nobility were now defended as servants of the state and as models of manners or cultivation serving as an exemplary spectacle for the rest of society (Amelang 1986). This practice-based conception, utilitarian or aesthetic, facilitated recruitment of ambitious bourgeois into the rank, but was strongly resisted by the old nobility, who became the object of intensive pedagogic efforts from the state in the form of public ceremonial, sumptuary laws, academies and military training, theatrical reforms, and so on. In Spain, for one, the nobility have still today failed to transform themselves completely into disciplined bourgeois subjects and continue to offer frequent unedifying spectacles to the lower orders. Thus the eighteenth Duchess of Alba, descendant of the famous Cayetana whose transgressive conduct was lovingly depicted by Goya and gave great anxiety to Enlightenment reformers ever preaching about "the duty of all nobility, which is to be exemplary" (Noyes 1998: 209), died in 2014 at the age of 88 after a career in which, via !Hola! magazine and other tabloids she served as an exemplar primarily of the dangers of excessive cosmetic surgery and the family tensions provoked by serial marriages to handsome younger men. Soon after her death, and in the aftermath of a range of scandals in the Spanish royal family, the young king Felipe VI gave a speech to the Grandees of Spain to call them back to order and exhort them to solidarity with a citizenship enduring economic crisis. The headline in El País read, "The king reminds the nobility of their duty to set an example through their conduct" ("El Rey recuerda..." 2015).

To be sure, the norm has served to discipline the Spanish monarchy at critical times. ${ }^{6}$ Juan Carlos I, of whom little had been expected after he was educated by Franco to help perpetuate the regime, rose to the most important occasion offered him, the attempted coup d'état of the new democracy by army officers in 1981. Responding to General Tejero's gesture of taking over the parliamentary session, Juan Carlos made his own gesture of refusal to allow the coup to take place in his name, affirming the new constitutional order. Growing unhappily lax in later life after no sacrifices were demanded of him, he took the initiative of abdicating in favor of his son in 2012 as a

\footnotetext{
${ }^{6}$ In the more familiar case of the British monarchy, the question has not been exclusively the observance or abrogation of the norm, but tension among different ideologies of exemplarity, with the Queen, Charles, and Diana each putting forward a different model.
} 
recognition of his failure. In turn, Felipe has shown considerable discipline in addressing the Spanish economic and constitutional crises and has not hesitated to make examples of his own family members imbricated in corruption scandals.

The Spanish example and other contemporary incidents in which sleeping canons are awakened into practice (Noyes 2015) suggest that residual exemplarity tends to take the form of a high-profile public gesture at a time of crisis. A heroic move that lends itself to representation and narration, it is less useful in maintaining everyday discipline: in fact, it is a response to failure and serves as a call to order.

By contrast, dominant exemplarity emphasizes everyday conduct, at least in principle. It is a central mechanism of what Gramsci calls cultural hegemony, as its function is to win consent and cooperation from the lower strata of society. We can identify this tradition with the modern ethos described by Max Weber as the Protestant ethic, a dynamic interaction of self-discipline, ambition, deferred gratification, and anxiety over one's reputation - the social mirror in which one is reassured of one's own salvation (1930 [1905]). This individualist ethos is thus nonetheless highly concerned with others, not only with peers but with predecessors and followers, that is, with the logic of influence and uptake. Within this framework, bad influences are to be avoided, and a good example is to be set: the conduct of the individual can lift up or damage everyone with whom she comes into contact. ${ }^{7}$ In contrast to the gestural character of residual codes, this internalized exemplarity requires continual self-monitoring and attention: gesture is reduced and regularized as conduct.

With its intensified emphasis on individual responsibility for outcomes, neoliberalism constitutes the social world as a field of models and influences. This exemplary logic has a homogenizing effect with implications for actors marked by ethnicity, gender, and so on. Bonnie Urciuoli speaks of "the peculiarly U.S. sense of community which emphasizes likeness, not relationships" (2008: 192). Marginal actors are judged by the degree to which they approximate the "cultural model of the white Anglo" (ibid.: 179), for it is understood that through "control and sacrifice" (ibid.: 184) they are capable of becoming "model citizens" and, collectively, a "model minority." Urciuoli argues that this polarized model of success and failure places marked populations under perpetual suspicion and hence a continual burden of performance: "The old model of the nonwhite as the un-American anticitizen is always lurking, and can only be fended off by constant exemplary effort" (ibid.: 194). In

\footnotetext{
${ }^{7}$ Hence the emphasis, in this modern logic, on certain positions combining visibility with leadership and supervision - the teacher, the cleric, the elected representative, whose conduct is thus especially open to disciplining and scandal. (Personal communication, Dani Schrire.) The frequency of failure of these institutionalized exemplars is crystallized in the American proverb, "Do as I say, not as I do."
} 
this way the neoliberal ideal of governmentality through self-management and autonomous motivation is never quite realized. Instead, subordinate populations are subject to ever more complex modalities of monitoring, complemented by ever-increasing opportunities for exemplary visibility. In the confidential arena of job performance review, for example, the expectation that employees will "Exceed Expectations" has produced a perpetual treadmill of running to stay in place. The public carrot to this private stick is the performance award. At the Ohio State University's College of Arts and Sciences, for example, where it is not easy for administrative staff to achieve promotion, one staff member per month wins an "Above and Beyond" award. This comprises a surprise visit to her department from the Dean, a prize of $\$ 200$, and recognition before her peers in university media. Given the small scale and frequent repetitions of such awards, it is not clear whether the awardee presents a transformative Vorbild or is merely put forward as a disciplinary Beispiel to illustrate a norm.

The paternalistic version of neoliberalism recognizes that populations at risk of failure must have role models; those in positions to set an example must cultivate "relatability" and empathy and seek out "teachable moments." A conspicuous case of such exemplarity may be found in the kitchen garden of the Obama White House, as explained by Puja Batra-Wells (2014). First Lady Michelle Obama, a Princeton-trained lawyer and accomplished professional, stooped to conquer as she entered the White House, embracing the role of "Mom-in-Chief" in order to improve the position of and exercise influence over American families, particularly American families of color. In response to an obesity epidemic affecting especially the poorer strata of society, and animated by more upper-middle-class concerns with health and environment, Obama oversaw the creation of an organic vegetable garden on the White House lawn to supply the presidential kitchen. She tied this to her own "Let's Move!" campaign intended to inspire young people of color to exercise. In public appearances she spoke frankly of her own challenges in giving her family healthy meals as she and her husband worked long hours for (relatively) little money. She described how she had gradually taken control of the family diet and made it a priority. This individual performance is complemented by a participatory pedagogy that levels the distinctions: she entertains groups of Washington D.C. schoolchildren at the garden, bringing them in to work with her and modelling both the care of the garden and the eating of its healthy products; she visits school gym classes and exercises with young people. Situated in an "exemplary site of authority in the public

\footnotetext{
${ }^{8}$ Conversely, of course, those who have had role models placed before them cannot plead ignorance as an excuse for failure. In Povedák's case study, however, the role model discourse has apparently arrived without any paternalist assumption of responsibility for making such provisions, so that one more reason to blame the Roma for their own situation is created.
} 
sphere" that is also a major tourist attraction (ibid.: 70), Obama "looks like America" in ways that previous First Ladies have not; she can more plausibly claim to be Beispiel as well as Vorbild. She has accepted the responsibility of this double cynosure by performing a certain American ethos: practice what you preach, so that your example can serve others.

As Batra-Wells and others observe, the calculus of neoliberal exemplarity renders itself suspect by failing to account for the material stage and props required to sustain the performance. In the case of the kitchen garden and healthy eating, the target audience of improvement generally lacks an uncontaminated and secure patch of ground on which to grow vegetables, a grocery store selling fresh vegetables, the time and energy to prepare daily healthy meals, and sometimes even a kitchen in which to do so. Exemplary displays such as the kitchen garden are, Batra-Wells argues, "compensatory technologies" at best (ibid.: 79).

As I have suggested, there is a broader contradiction destabilizing the dominant exemplarity. It is deep in the liberal ideology that constructs mobility and progress as norms, for example in the American ideal of citizenship that understands "old country heritage" as "point of departure" (Urciuoli 2008: 187). In this framework, staying in place, however effortful, is not exemplary. Exacerbating the contradiction of transformation as norm are the social conditions of visibility. The attention economy lends itself to a spectacular exemplarity of gesture rather than the slow exemplarity of conduct.

And so we come to the most interesting but least graspable domain of emergent exemplarity: new or alternative models of influence and the content of those models themselves. We are inclined to associate new modes of influence with transformative change - the charismatic example that breaks earlier patterns of cultural reproduction. Here I have more questions than answers. Researchers will want to consider how exemplarity changes with the nature of mediation - what happens with social media and the phenomenon of "going viral"? Linking this popular circulation to the amplification effected by commercial media's publicity machines and such nonprofit talking shops as the TED conference, individuals aiming to set examples can achieve worldwide, nearly instantaneous reach, which will also be ephemeral, subject to backlash and to distraction from the next big thing. Consider for example, the Greg Mortenson phenomenon, in which a 2007 mountaineer's memoir of building a village school in northern Pakistan became a bestseller, instigated the creation of a charity for which thousands of American schoolchildren collected funds, and influenced the U.S. counterinsurgency campaign in Afghanistan. Four years later the memoir's facts were challenged, along with the efficacy of the charity's activities and the propriety of its expenditures, in a series of exposés. In 2012 Malala Yousafzai replaced Mortenson as the exemplary face, for Western audiences, of education for girls in non-Western 
regions. At the time of this writing there has been no Western backlash against her, but the media emphasis on her personal story and individual heroism arguably gets in the way of her activist agenda and the activist efforts of others, highlighting the limits of exemplarity in the sentimental or empathetic mode (Hesford 2014).

The dissident exemplarity of extremist groups takes a mixed approach. They speak to a world audience through a "propaganda by the deed" descending from early anarchist thought: the use of spectacular public actions of violence to destabilize the order of appearances and make further disruptive actions thinkable (cf. Scott 1990). Recruitment takes place more powerfully, however, through networked communications that make skilled use of social media and professional production values, as seen in the Islamic State recruitment videos that encourage young westerners to identify with suicide bombers (Koerner 2016). The common threads among these emergent exemplarities seem to be social media as the primary channel of transmission and identification as the mode of appeal.

\section{EXEMPLARS IN THE SOCIAL FIELD}

The case studies on our panel can be distributed across a field of social process. In the diagram below, one axis stands between stability and transformation. The other pits hierarchical against horizontal vectors of transmission.

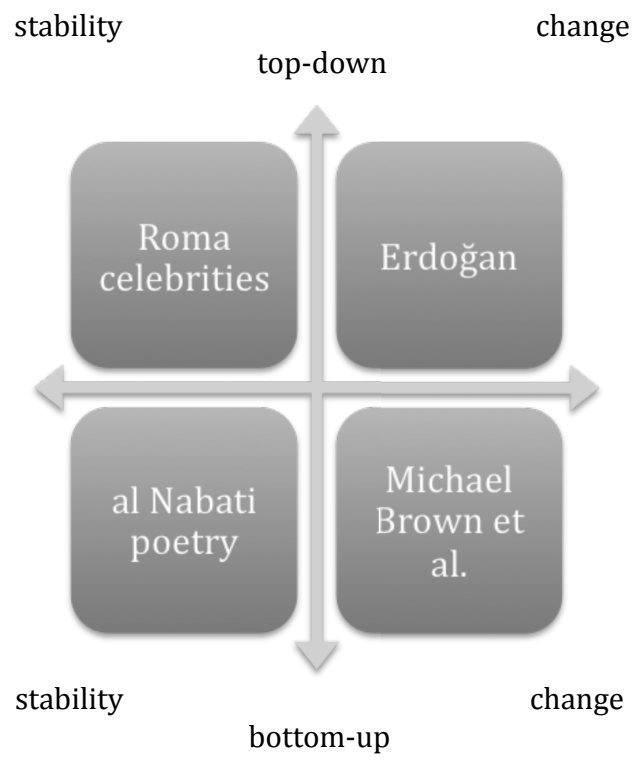


While reducing and distorting the examples, such a schema makes the operations of power more visible.

If we begin with the bottom left quadrant, we see a face-to-face social exemplarity that has expanded modestly outward with the publication of Shamsa al Falahi's poems. Accustomed to exercising a domestic authority that is legitimated through kinship ties to past exemplars, Shamsa neither gestures toward a utopia nor back to a golden age, but attempts instead to reconcile past and present through a shared poetic idiom. Her emphasis is on mimesis in the present more than the example of the past. More broadly in this quadrant we find the social reproduction of traditional authority through example and imitation in the intimate sphere and everyday interactions.

Moving up to the top left, we find the Foucauldian zone in which individuals are disciplined by the imposition of exemplars, positive or negative. Foucault of course sees a historical transition between the early modern "making an example of" a criminal through spectacular public punishment and the properly modern culture of surveillance and the internalization of norms (1975). But examples are key to both phases: the negative example is replaced by the positive role model, the normative image. And, as suggested above, the residual model is alive and well in workplaces, classrooms, policing, and elsewhere.

Povedák's case study of a population still subject to open discrimination and active repression finds that Hungarian Roma public figures are forced into a blend of three figurations: the stereotype, the celebrity, and the role model. Canonized by popularity rather than by authority, the Romani musician or sports hero is the only Roma individual visible before a broad public, given the practical exclusion of Roma from other public roles such as elected official, business leader, or intellectual. Both the stereotype of Roma and the formats and conventions of celebrity impede the emergence of role models. Inhabiting gossip columns and reality television, celebrities today are more transgressive than exemplary in the usual sense: they garner and maintain attention by erratic flareups and bouts of bad behavior. Roma also give pleasure to a general audience when they are seen to behave like Roma: playing music, making jokes, indexing a supposedly carefree and rule-free mode of life. Povedák cites a Romani football player, successful and wealthy, who has funded the building of a school in his native village and returns regularly to look after it, an ideal role model whose actions have not been taken up by Hungarian media. Conversely, Povedák notes a tendency among Romani activist websites to construct a canon of heroes by claiming Roma origins for celebrated musicians (Robert Plant), actors (Charlie Chaplin), and politicians (Bill Clinton, famously seen also by other minorities as an exemplar with whom they can identify because of his hybrid public image). ${ }^{9}$ Like other

${ }^{9}$ The novelist Toni Morrison called him “our first black president" (1998). 
visible members of minorities, Roma celebrities are taxed with the burden of representation: their actions compromise or, less often, lend legitimacy to all members of the group. In any case, the neoliberal assertion that role models should motivate individuals to overcome their circumstances hits its limit in conditions of such systemic discrimination.

Both of these are stabilizing examples. The al Nabati poetry, which maintains the authority of tradition, also coincides comfortably with the shape of state power in that part of the world. Roma role models, compromised as they are, do not empower individuals to revise the world as they see fit, but rather seek to make individuals fit for the world as it is. What about the transformative intent we see on the other half of the diagram?

Here I will call us back to Jolles, and another of his simple forms. If his Legende is connected to example as Vorbild or model, another genre, the Kasus, is connected, albeit problematically, to Beispiel, the representative case. The Kasus, in Jolles' definition, is a case raising a question of interpretation in relation to norms: the legal case is of course his paradigm. In contrast to the gesture of the Legende, which makes a norm visible, in the Kasus it is contradiction that is made visible, through the particularity and contingency of narrative events (1930: 179). We might consider the transformative example as a hybrid of the two, the model interacting with history and a new model emerging from the process.

Erdoğan's defiance, as described by Demirer, certainly provoked mimesis but in the first instance it simply invited broadcast, winning massive uptake from Middle Eastern media channels. The president sought to highlight contradictions and make them visible to the broad public he claimed to represent. His gesture defined the behavior of the Davos moderator as a Beispiel of Western hypocrisy in the treatment of Middle Eastern and Muslim actors. Significantly, Erdoğan did not dismiss Habermasian norms of fairness, equality, and respect; rather he appealed to them in declaring their violation. In addition, during the interaction he also appealed to principles of traditional authority avowed by his Israeli interlocutor Shimon Peres: age, position, religion, respect. His rhetorical move was to show both Davos and Israel as breaking their own rules, and the exemplary gesture was a public demand for accountability. ${ }^{10}$

The case of Michael Brown and the others described by Borland illustrates a rhetorical relocation from my diagram's top left quadrant, the

${ }^{10}$ Within his own sphere of authority, Erdoğan has of course revitalized the residual technique of making examples of dissenters, and on the international stage he is currently a conspicuous link in the chain of charismatic authoritarian leaders defying democratic norms and posing a potentially transformative challenge to democratic governance. Thus his deference to norms in this instance can be seen as a tactical maneuver within a strategy aimed elsewhere. 
disciplinary examples, to the bottom right: the gestures toward utopia. Here it was the uptakers, the activists of Central American solidarity movements and \#BlackLivesMatter, who reanimated violent events in order to highlight the contradiction they embody: again one in which modern rational-legal authority violates its own commitment to impersonality and fairness. Borland's paper, after elucidating this tactic, highlights a risk inherent in its "techniques of identification," the bodily mimesis of chanting "I can't breathe" or lying on the ground in a "die-in." As with the case of Malala Yousafzai, raised above, or of the Charlie Hebdo shootings (discussed by Kapchan in this issue), the "I am-" trope, when deployed by sympathizers positioned differently from the victims, can claim a privileged innocence. At best, its emotional force tends to cloud analysis.

The mode of solidarity as identification can foster an assumption of responsibility, and this gesture goes deep in Western culture. In Lope de Vega's 1619 play Fuenteovejuna, villagers unite to declare "Fuenteovejuna did it!" when the killing of an abusive feudal lord is investigated. Similarly in Stanley Kubrick's McCarthy-era film Spartacus (1960), Roman slaves refuse, one by one, the role of informer against a rebel, each declaring "I am Spartacus!" This gestural conclusion is updated in Spike Lee's Malcolm X (1992). But given the pitfalls of mediated identification among strangers, other strategies suggest themselves today. Those of us who cannot reasonably claim positional identification with the victims of a given atrocity might try the imaginative exercise of identifying with the perpetrators, in order to recognize the avenues by which privileged actors can become complicit. ${ }^{11}$ And, as Danielle Marx-Scouras suggests, solidarity campaigns need not resort to "I am-." An alternative slogan was devised in the 1980s by the French campaign SOS Racisme: "Touche pas à mon pote" (Hands off my pal)(2015). ${ }^{12}$ With this approach, privileging attention rather than identification, the Vorbild need not be a Beispiel, and room for cooperation and emulation within a plural society is opened up.

${ }^{11}$ To be sure there is real risk of such an exercise going the other way and generating tolerance of atrocity. But it is surely worthwhile for middle-class white Americans to recognize how they might have become the neighborhood vigilante who shot Trayvon Martin or for police officers to reconsider the pathways of practical reason and reaction that generate the deaths of so many African Americans.

12 This model has recently been adapted in Turkey in the "Hands off my colleague" campaign in solidarity with members of the "Academics for Peace" organization currently under judicial investigation. For a theoretical grounding, we might consider Tim Ingold's account of the coexistence of human and animal agents as spatiotemporal lines that move side by side, sometimes diverging, sometimes coming close or entangling (2007). 


\section{CONCLUSION}

Exemplarity is a special case of tradition. Like the oral traditions whose workings have been more fully studied, it moves from performance to performance through conventions that render it recognizable and encourage some actors to codify it as a langue (Bauman and Briggs 1990). It can be captured in text or image but is most immediately understood to lodge within persons as a holistic contour defining either a specific act or a longer arc of conduct.

The exemplar is a particular individual whose act or conduct is claimed, through gesture, in a subsequent performance. An exemplar is a Vorbild, but the specificity and contingency of both the exemplary and the emulating performances raise questions of Beispiel: what and whom the example represents. Within this interplay lie both the disciplinary and the latent critical potential of exemplary performance. As with tradition in general, exemplarity stands in a constant tension between propertization and transmission. ${ }^{13}$ There are those who lay claim to the example, or impose it upon others. There are also those who assume responsibility for carrying it forward. Unlike those practices usually labelled as tradition, however, exemplarity is in no way marginal to Western modernity, but central to the history of its imaginings of power, progress, and the self. In this essay I have sought to inaugurate a holistic theorization of the topic.

\section{REFERENCES AND SOURCES}

Agha, Asif. 2007. Language and Social Relations. Cambridge: Cambridge University Press.

Amelang, James. 1986. Honored Citizens of Barcelona. Patrician Culture and Class Relations, 1490-1714. Princeton: Princeton University Press.

Bakhtin, Mikhail M. 1982. The Dialogic Imagination. Four Essays. Michael Holquist, ed. Austin: University of Texas Press.

Batra-Wells, Puja. 2014. "Pruning the Bio-Political Subject. The Obama Garden as Neo-Liberal Display." In Politische Mahlzeiten. Political Meals. Regina F. Bendix and Michaela Fenske, eds. Münster: LIT Verlag, 67-80.

Bauman, Richard et al. 1977. Verbal Art as Performance. Prospect Heights IL: Waveland Press.

Bauman, Richard 1986. "Performance and Honor in 13th-Century Iceland." Journal of American Folklore 99: 131-150. [http://dx.doi.org/10.2307/539970]

Bauman, Richard and Charles L. Briggs. 1990. "Poetics and Performance as Critical Perspectives on Language and Social Life." Annual Review of Anthropology 19: 59-88. [http:// dx.doi.org/10.1146/annurev.an.19.100190.000423]

\footnotetext{
${ }^{13}$ In Noyes 2016, chapter 4, I take up this tension and put forward a model of tradition as a transfer of responsibility, building upon the Hymes-Bauman definition of performance as the acceptance of responsibility for a display of communicative competence before an audience.
} 
Borland, Katherine. 2015 "The Afterlife of Martyrs." Paper presented in the panel "Gesturing Toward Utopia: The Politics of Exemplarity." Utopias Realities Heritages, 12th Congress, Société Internationale d'Ethnologie et de Folklore, Zagreb, 22 June.

Brémond, Claude, Jacques Le Goff and Jean-Claude Schmitt, eds. 1996. L'Exemplum, 2d ed. Typologie des sources du Moyen Âge occidental, 40. Turnhout: Brepols.

Briggs, Charles L. and Richard Bauman. 1992. "Genre, Intertextuality, and Social Power." Journal of Linguistic Anthropology 2: 131-172. [http://dx.doi.org/10.1525/jlin.1992.2.2.131]

Cantwell, Robert. 1993. Ethnomimesis. Folklife and the Representation of Culture. Chapel Hill: University of North Carolina Press.

Cashman, Ray. 2008. Storytelling on the Northern Irish Border. Characters and Community. Bloomington: Indiana University Press.

Cashman, Ray, Tom Mould and Pravina Shukla, eds. 2011. The Individual and Tradition. Folkloristic Perspectives. Bloomington: Indiana University Press.

Dayan, Daniel and Elihu Katz. 1994. Media Events. The Live Broadcasting of History. Cambridge: Harvard University Press.

Demirer, Yücel. 2015. "The Interaction between Exemplarity and Political Process. The Case of Turkish President Erdoğan's 'One Minute' Angry Walkout at the 2009 Davos Meeting." Paper presented in the panel "Gesturing Toward Utopia: The Politics of Exemplarity." Utopias Realities Heritages, 12th Congress, Société Internationale d'Ethnologie et de Folklore, Zagreb, 22 June.

Douglas, Mary. 1970. Natural Symbols. Explorations in Cosmology. London: Barrie and Rockcliff.

"El Rey recuerda que los nobles deben dar ejemplo con su comportamiento." 2015. El País, 16 June. Available at: http://elpais.com/elpais/2015/06/16/estilo/1434455748_200188. html (accessed 1 May 2016).

Fernandez, James W. 1986. Persuasions and Performances. The Play of Tropes in Culture. Bloomington: Indiana University Press.

Foucault, Michel. 1975. Discipline and Punish. The Birth of the Prison. New York: Random House.

Fischer, Torben and Matthias N. Lorenz, eds. 2007. Lexikon der "Vergangenheitsbewältigung" in Deutschland. Debatten- und Diskursgeschichte des Nationalsozialismus nach 1945. Bielefeld: Transcript Verlag.

Hesford, Wendy. 2014. "The Malala Effect". JAC: Quarterly Journal for the Interdisciplinary Study of Rhetoric, Culture, Literacy, and Politics 34: 139-164.

Hill, Jane H. and Judith T. Irvine, eds. 1993. Responsibility and Evidence in Oral Discourse. Cambridge: Cambridge University Press.

Ingold, Tim. 2007. Lines. A Brief History. New York: Routledge.

Jolles, André. 2011 [1930]. Einfache Formen. Digitale Bibliothek voor de Nederlandse letteren. Available at: http://www.dbnl.org/tekst/joll001einf01_01/colofon.php (accessed 1 May 2016).

Koerner, Brendan I. 2016. "Why ISIS is Winning the Social Media War." Wired, April. Available at: http://www.wired.com/2016/03/isis-winning-social-media-war-heres-beat/ (accessed 1 May 2016).

Lévi-Strauss, Claude. 1962. La pensée sauvage. Paris: Plon.

Marx-Scouras, Danielle. 2015. Remarks at "Charlie Hebdo and January 7. A Mini-Symposium and Conversation." Billy Ireland Cartoon Library and Museum, The Ohio State University, 19 February. 
Mendoza-Denton, Norma. 2008. Homegirls. Language and Cultural Practice Among Latina Youth Gangs. Malden, MA, Oxford: Blackwell.

Morrison, Toni. 1998. "Comment". The New Yorker, 5 October.

Müller, Matthias. 2012. Die SPD und die Vertriebenenverbände 1949-1977: Eintracht, Entfremdung, Zwietracht. Münster: LIT Verlag.

Noyes, Dorothy. 1998. "La maja vestida: Dress as Resistance to Enlightenment in Late 18th-Century Madrid". Journal of American Folklore 111: 197-218. [http://dx.doi. org/10.2307/541941]

Noyes, Dorothy. 2001. "Authoring the Social Drama. Suicide, Self, and Narration in a French Political Scandal". Narrative 8: 210-231.

Noyes, Dorothy. 2013. "The Theater of Clemency". The Politics of Compassion. Michael Ure and Mervyn Frost, eds. New York: Routledge, 208-229.

Noyes, Dorothy. 2015. "Inimitable Examples. School Texts and the Classical Register in Contemporary French Politics". Registers of Communication. Asif Agha and Frog, eds. Studia Fennica Linguistica 18. Helsinki: Finnish Literature Society, 210-221.

Noyes, Dorothy. 2016. Humble Theory. Folklore's Grasp on Social Life. Bloomington: Indiana University Press.

Povedák, István, ed. 2014. Heroes and Celebrities in Central and Eastern Europe. Bibliotheca Religionis Popularis Szegediensis, 37. Szeged: Department of Ethnology and Cultural Anthropology.

Povedák, István. 2015. “And What to Do When There's Nobody to Follow? The Public Image of Romani Heroes and Celebrities". Paper presented in the panel "Gesturing Toward Utopia: The Politics of Exemplarity." Utopias Realities Heritages, 12th Congress, Société Internationale d'Ethnologie et de Folklore, Zagreb, 22 June.

Raglan, Lord (FitzRoy Somerset). 1936. The Hero. A Study in Tradition, Myth and Drama. London: Methuen.

Rainey, Elizabeth. 2015. "Domestic Utopias. Emirati al Nabati Poetry As an Agent of Personal, Social and National Transformation". Paper presented in the panel "Gesturing Toward Utopia: The Politics of Exemplarity." Utopias Realities Heritages, 12th Congress, Société Internationale d'Ethnologie et de Folklore, Zagreb, 22 June.

Roberts, John W. 1990. From Trickster to Badman. The Black Folk Hero in Slavery and Freedom. Philadelphia: University of Pennsylvania Press.

Schmitt, Jean-Claude, ed. 1983. Les Saints et les Stars. Le texte hagiographique dans la culture populaire. Paris: Beauchesne.

Scott, James 1990. Domination and the Arts of Resistance. New Haven: Yale University Press.

Shuman, Amy. 2010. Other People's Stories. Entitlement Claims and the Critique of Empathy. Urbana: University of Illinois Press.

Suellentrop, Chris. 2002 “Can You Trademark the Phrase 'Let's Roll'?” Slate 27 February. Available at: http://www.slate.com/articles/news_and_politics/explainer/2002/02/can_you_ trademark_the_phrase_lets_roll.html (accessed 1 May 2016).

Theoharis, Jeanne. 2013. The Rebellious Life of Mrs. Rosa Parks. Boston: Beacon Press.

Turner, Victor. 1975. Dramas, Fields, and Metaphors. Symbolic Action in Human Society. Ithaca: Cornell

Urciuoli, Bonnie. 2008. "Skills and Selves in the New Workplace". American Ethnologist 35: 211-228. [http://dx.doi.org/10.1111/j.1548-1425.2008.00031.x] 
Weber, Max. 1930 (1905). The Protestant Ethic and the Spirit of Capitalism. New York: Scribners.

Williams, Raymond. 1977. Marxism and Literature. Oxford: Oxford University Press.

Wolffsohn, Michael and Thomas Brechenmacher 2010. “'Der Kanzler hat gekniet.' Brandts Kniefall--ein Leitstern der Politik." Warsaw: Rapporte der Konrad-Adenauer-Stiftung in Polen, 16. Available at: www.kas.de/wf/doc/kas_21141-1522-1-30.pdf?101117204233 (accessed 1 May 2016).

Young, Katharine Galloway. 2011. "Gestures, Intercorporeity, and the Fate of Phenomenology in Folklore". Journal of American Folklore 124: 55-87.

\section{GESTAMA PREMA UTOPIJI: PREMA TEORIJI EGZEMPLARNOSTI}

Na temelju sažetka panela s kongresa SIEF-a iz 2015. godine, u radu se bavim sintezom folklorističkih i etnoloških izvora kako bih razvila teoriju egzemplarnosti. Egzemplarnost smatram posebnim slučajem tradicije, koji nije marginalan, nego centralan u zapadnjačkim diskursima moći, napretka i sebstva. Normativna snaga kao i kritički potencijal egzemplarnosti proizlaze iz dvoznačnosti samog pojma, koji može označavati ono što se u njemačkom razlikuje kao Vorbild i Beispil, odnosno uzor i predstavnik. Je li nam uzor dovoljno blizak da ga možemo oponašati? Je li nam nametnut pa time i neizbježan? Gesta koja omogućuje oponašanje egzemplara ujedno ga čini podložnim ekonomiji pažnje: neki postupak nije egzemplar sve dok ga netko ne preuzme i ne počne oponašati, a geste ponavljanjem ujedno gube snagu. Stoga, tri modaliteta egzemplarnosti - rezidualni, dominantni i emergentni - ne ovise samo o promjeni povijesnih oblika moći, nego i o promjeni načina posredovanja. Kako bih pokazala da egzemplarnost može za cilj imati ustaljivanje ili mijenjanje, dajem sažetak analiza sudionika panela. Analize su se bavile prizivanjem običaja predaka u slučaju beduinske pjesnikinje (Elizabeth Rainey), romskim slavnim osobama u Istočnoj Europi (István Povedák), gnjevnim izlaskom turskog predsjednika Erdoğana sa sastanka u Davosu 2009. godine (Yücel Demirer) i "tehnikama identifikacije" aktivista (Katherine Borland).

Ključne riječi: egzemplarnost, gesta, izvedba, politički simbolizam, pojedinac, ekonomija pažnje 